\title{
Bromine a product of the distillation of coal
}

\section{Mene}

To cite this article: M. Mene (1850) Bromine a product of the distillation of coal, Philosophical Magazine Series 3, 37:250, 317-317, DOI: 10.1080/14786445008646616

To link to this article: http://dx.doi.org/10.1080/14786445008646616

册 Published online: 30 Apr 2009.

Submit your article to this journal $\pi$

Џ Article views: 2

Q View related articles $₫$ 


\section{ON THE EXTRACTION OF IODINE FROM PLANTS AND FROM COAL. BY M. BUSSY.}

Some doubts having been expressed by several persons in the Academy with respect to the accuracy of the statements respecting the existence of iodine in certain plants, the author deposited a specimen of cress and of the iodine which he had obtained from it, and also of iodide of potassium procured from the same plant.

M. Bussy also remarks that in $\mathbf{1 8 3 9}$ he showed that the coal of Commentry contains iodine. Some portions of this coal contain much sulphuret of iron; whence it happens that whilst working, masses often undergo a kind of slow combustion. The heat thus produced gives rise to thick vapours which condense on the surface, and the product is found to consist of sulphuret and other arsenical compounds, with much sal-ammoniac, contrining hydriodate of ammonia: at the period mentioned the author merely stated the peculiar reactions of iodine, without trying to isolate it. Not having any of the natural product in his possession in which he had first met with iodine, he had recourse to the products of the distillation of coal for obtaining gas; and he found in the ammoniacal liquor a considerable quantity of iodine, and such as he could separate and estimate.

The process which he adopted was to add to a certain quantity of the condensed water enough potash to convert the hydriodate of ammonia into iodide of potassium; by evaporation to dryness and calcination, the tarry matter was destroyed; and the residue being treated with alcohol, yielded iodide of potassium. The iodine was estimated by means of iodide of palladium, by the decomposition of which by heat iodine", was obtained, of which a specimen was presented to the Academy.

Three kilogrammes of the condensed water of the establishment at the barrière of Fontainebleau yielded $0.59 \mathrm{gr}$. of iodine, nearly 0.2 per kilogramme, or 2 ten-thousandths : iodine was also found in the liquor of another establishment, which renders it probable that it will be found in all varieties of coal.

M. Bussy remarks that the quantity stated does not include the whole of the iodine contained in the coal, since a quantity remains in the coke, which may be obtained by incineration.

M. Bussy observes, that the distilled product of gas-works may possibly be employed for the ceconomical preparation of iodine, especially if it could be obtained without prejudice to the separation of the ammoniacal salts.-L'Institut, No. 853 .

\section{BRomine a PROdUCt of the Distillation of CoAl. BY M. MENE.}

The author, who is chemical assistant at the College of France, states that he has discovered bromine in the ammoniacal liquor obtained as above mentioned. He has also found the iodine previously mentioned by M. Bussy.-Ibid. No. 854. 